\title{
1-n-Butyl-3-methylimidazolium-2-carboxylate: a versatile precatalyst for the ring-opening polymerization of $\varepsilon$-caprolactone and rac-lactide under solvent-free conditions
}

\author{
Astrid Hoppe, Faten Sadaka, Claire-Hélène Brachais, Gilles Boni, \\ Jean-Pierre Couvercelle and Laurent Plasseraud ${ }^{*}$
}

\section{Letter}

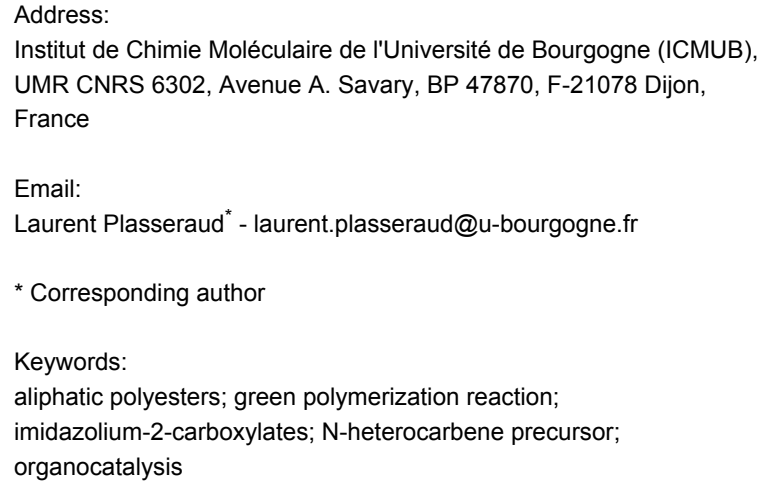

Beilstein J. Org. Chem. 2013, 9, 647-654.

doi:10.3762/bjoc.9.73

Received: 13 December 2012

Accepted: 07 March 2013

Published: 03 April 2013

Associate Editor: H. Ritter

(C) 2013 Hoppe et al; licensee Beilstein-Institut. License and terms: see end of document.

\begin{abstract}
The ring-opening polymerization of $\varepsilon$-caprolactone ( $\varepsilon$ - $\mathrm{CL})$ and $r a c$-lactide $(r a c$-LA) under solvent-free conditions and using 1-nbutyl-3-methylimidazolium-2-carboxylate (BMIM-2- $\mathrm{CO}_{2}$ ) as precatalyst is described. Linear and star-branched polyesters were synthesized by successive use of benzyl alcohol, ethylene glycol, glycerol and pentaerythritol as initiator alcohols, and the products were fully characterized by ${ }^{1} \mathrm{H}$ and ${ }^{13} \mathrm{C}\left\{{ }^{1} \mathrm{H}\right\}$ NMR spectroscopy, gel permeation chromatography (GPC), and differential scanning calorimetry (DSC). BMIM-2- $\mathrm{CO}_{2}$ acts as an N-heterocyclic carbene precursor, resulting from in situ decarboxylation, either by heating under vacuo (method A) or by addition of $\mathrm{NaBPh}_{4}$ (method B). Possible catalytic and deactivation mechanisms are proposed.
\end{abstract}

\section{Introduction}

Poly(E-caprolactone) (PCL) and polylactic acid (PLA) are biologically relevant aliphatic polyesters. Their applications vary, due to their compatibility with other polymers and their biodegradability, from packaging to pharmaceutics and medicine [1-6]. PCL serves for instance as a scaffold for tissue engi- neering [7,8] and as a carrier of stem cells [9], PLA as an implant material for stents and screws [10]. A general synthetic route for polyesters with controlled molecular weight and distribution requires the use of metal alkoxides and catalysts of transition, rare-earth and alkali metals, as initiators for the ring- 
opening polymerization (ROP) of cyclic esters. During the past decade, numerous articles and reviews have been published, which shows a growing interest for this research area [11-18]. However, in order to avoid the use of metal-based catalysts, which are unwanted in medical applications, great efforts have been made recently to develop metal-free organo-catalysts [1927]. In this context, ROP promoted by N-heterocyclic carbenes (NHCs) is an alternative route. Indeed, previous studies have shown that NHCs provide versatile catalyst activities with high efficiencies and molecular-weight control [20,27-32]. Their selectivity and conversion rate are influenced by the nature of the monomer and the carbene used. Sterically encumbered carbenes, such as 1,3-dimesitylimidazol-2-ylidene (IMes, Figure 1), are known to be highly active for the ROP of raclactide [20,27,31,33], while less encumbered and electronically rich carbenes such as 1,3,4,5-tetramethylimidazol-2-ylidene (ImMe4, Figure 1) show a higher activity towards the ROP of $\varepsilon$-caprolactone [28,34]. Thus, the design of a versatile catalyst for both reactions still remains a challenge.

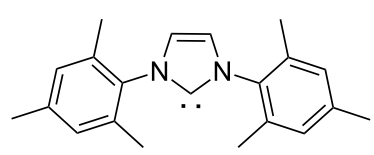<smiles></smiles>

IMes

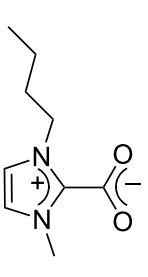

BMIM-2- $\mathrm{CO}_{2}$
Figure 1: Molecular representations of $\mathrm{N}$-heterocyclic carbenes and BMIM-2- $\mathrm{CO}_{2}$.

In this quest and encouraged by our previous results, we chose to explore the potential of zwitterionic 1- $n$-butyl-3-methylimidazolium-2-carboxylate (BMIM-2- $\mathrm{CO}_{2}$, Figure 1). Indeed, methylimidazolium-2-carboxylates can be easily synthesized with high yields by the one-pot reaction of dimethyl carbonate (DMC) with imidazole derivatives, making them very attractive and accessible compounds [35]. Therefore, they found applications as ligands in organometallic catalysis [36-41], as precursors of halide-free ionic liquids [42-45], and as organocatalysts in reactions involving carbon dioxide transfer in the formation of ketoacetates [46,47] and carboxylation of epoxides [48]. Some of us have recently reported a green application of BMIM-2- $\mathrm{CO}_{2}$, highlighting its efficiency for the conversion of raw glycerol to glycerol carbonate by transesterification [49]. More recently, this concept was extended to the synthesis of aliphatic polycarbonates, involving the transesterification of DMC with linear alkane diols under solvent-free conditions, and based on a two-step polymerization process
[50]. The high reactivity of imidazolium-2-carboxylates can be explained by their facile decarboxylation, thus generating active carbene species, which occurs either by heating [51] or by the addition of $\mathrm{Na}^{+}$or $\mathrm{K}^{+}\left(\mathrm{NaBPh}_{4}, \mathrm{KPF}_{6}\right)$ [47]. In this paper, we apply this dual approach to the solvent-free ROP of $\varepsilon$-caprolactone and rac-lactide using 1-n-butyl-3-methylimidazolium-2carboxylate (BMIM-2- $\mathrm{CO}_{2}$ ) as a precatalyst.

\section{Results and Discussion}

Two solvent-free polymerization procedures were developed in this study, named methods A and B (Scheme 1). Four initiator alcohols, with an increasing number of $\mathrm{OH}$ functions, were successively used: benzyl alcohol (1), ethylene glycol (2), glycerol (3) or pentaerythritol (4) (Scheme 1).<smiles>O=C1CCCCO1</smiles>

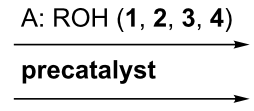
$\mathrm{B}: \mathrm{ROH}(1)$ $\varepsilon$-caprolactone<smiles>CC1OC(=O)C(C)OC1=O</smiles>

rac-lactide

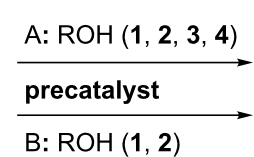

B: ROH (1, 2)<smiles>[R6]C(C)=O</smiles>

PCL

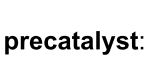<smiles></smiles><smiles>[R]OC(C)C(C)OCC</smiles>

PLA
$\mathrm{ROH}:$<smiles>OCc1ccccc1</smiles><smiles>OCCO</smiles><smiles>OCC(O)CO</smiles>

3

Scheme 1: Ring-opening polymerization of $\varepsilon$-caprolactone and raclactide by using BMIM-2- $\mathrm{CO}_{2}$ as precatalyst ( $1 \mathrm{~mol} \%$ ), and in the presence of alcohol initiators $\operatorname{ROH}(1,2,3,4)$. Method A: solvent-free conditions, in vacuo, $75^{\circ} \mathrm{C}, 75 \mathrm{~min}$; method $\mathrm{B}$ : solvent-free conditions, $\mathrm{NaBPh}_{4}(0.5 \mathrm{~mol} \%)$ as decarboxylating agent, $75^{\circ} \mathrm{C}, 120 \mathrm{~min}$.

The ROPs of $\varepsilon$-CL and $r a c$-LA were firstly investigated by heating in vacuo at $75{ }^{\circ} \mathrm{C}$ for $75 \min (\operatorname{method} \mathrm{A})$, studying the influence of the amount and the nature of the initiator alcohols. Linear and star-branched polyesters were synthesized and fully characterized by ${ }^{1} \mathrm{H}$ and ${ }^{13} \mathrm{C}\left\{{ }^{1} \mathrm{H}\right\}$ NMR spectroscopy, gel permeation chromatography (GPC) and differential scanning calorimetry (DSC). Polymerization data are summarized in Table 1 and Table 2. 
Table 1: Ring-opening polymerization of $\varepsilon-C L$ in the presence of alcohol initiator [benzyl alcohol (1), ethylene glycol (2), glycerol (3) or pentaerythritol (4)], initiated in vacuo at $75^{\circ} \mathrm{C}$ for $75 \mathrm{~min}$.

\begin{tabular}{|c|c|c|c|c|c|c|c|c|c|c|c|}
\hline entry & $\begin{array}{c}1 \\
\mathrm{mmol}\end{array}$ & $\begin{array}{c}2 \\
\mathrm{mmol}\end{array}$ & $\begin{array}{c}3 \\
\mathrm{mmol}\end{array}$ & $\begin{array}{c}4 \\
\mathrm{mmol}\end{array}$ & $M / I^{a}$ & $1 / C^{b}$ & $\begin{array}{c}M_{\mathrm{n}}{ }^{\mathrm{C}} \\
\text { (theor.) }\end{array}$ & $M_{\mathrm{n}}^{\mathrm{d}}$ & $M_{\mathrm{n}}^{\mathrm{e}}$ & PDIf & $\underset{\%}{\text { conv. }^{d}}$ \\
\hline $1 a$ & 0.10 & - & - & - & 90 & 2 & 6927 & 2730 & 2950 & 1.40 & 100 \\
\hline $1 b$ & 0.48 & - & - & - & 19 & 8 & 2031 & 1130 & 2280 & 1.49 & 100 \\
\hline $1 \mathrm{c}$ & 0.96 & - & - & - & 9 & 19 & 1120 & 680 & 780 & 1.53 & 100 \\
\hline $1 d$ & 1.92 & - & - & - & 5 & 38 & 629 & 450 & 340 & 1.93 & 100 \\
\hline $2 a$ & - & 0.18 & - & - & 50 & 3 & 4508 & 1090 & 1270 & 1.50 & 100 \\
\hline $2 b$ & - & 0.89 & - & - & 10 & 18 & 1158 & 600 & 490 & 1.86 & 100 \\
\hline $2 c$ & - & 1.79 & - & - & 5 & 36 & 621 & 400 & 360 & 2.22 & 100 \\
\hline $2 d$ & - & 3.58 & - & - & 3 & 72 & 346 & 290 & 310 & 1.95 & 100 \\
\hline $3 a$ & - & - & 0.14 & - & 64 & 3 & 5416 & 1580 & 2520 & 1.75 & 100 \\
\hline $3 b$ & - & - & 0.68 & - & 13 & 11 & 1477 & 1460 & 2390 & 1.91 & 100 \\
\hline $3 c$ & - & - & 1.37 & - & 7 & 23 & 817 & 770 & 830 & 1.98 & 100 \\
\hline $3 d$ & - & - & 2.74 & - & 3 & 46 & 411 & 660 & 750 & 2.06 & 100 \\
\hline $4 a$ & - & - & - & 0.15 & 60 & 3 & 5181 & 1960 & 11700 & 1.23 & 100 \\
\hline $4 b$ & - & - & - & 0.50 & 18 & 10 & 2009 & 1163 & 5840 & 1.50 & 100 \\
\hline $4 c$ & - & - & - & 0.96 & 10 & 19 & 1157 & 593 & 2340 & 1.66 & 100 \\
\hline $4 d$ & - & - & - & 1.99 & 5 & 40 & 639 & 479 & 1330 & 1.79 & 100 \\
\hline
\end{tabular}

aMonomer to initiator ratio. ${ }^{b}$ Initiator to catalyst ratio. ${ }^{c}$ Calculated according to Equation 1 and Equation $2 .{ }^{d}$ Determined by ${ }^{1} \mathrm{H}$ NMR spectroscopy.

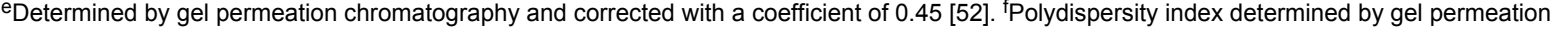
chromatography.

Table 2: Ring-opening polymerization of rac-lactide in the presence of alcohol initiators [benzyl alcohol (1), ethylene glycol (2), glycerol (3)] ${ }^{\mathrm{a}}$, initiated in vacuo at $75^{\circ} \mathrm{C}$ for $75 \mathrm{~min}$.

\begin{tabular}{|c|c|c|c|c|c|c|c|c|c|c|}
\hline entry & $\begin{array}{c}1 \\
\mathrm{mmol}\end{array}$ & $\begin{array}{c}2 \\
\mathrm{mmol}\end{array}$ & $\begin{array}{c}3 \\
\mathrm{mmol}\end{array}$ & $\mathrm{M} / \mathrm{I}^{\mathrm{b}}$ & $1 / C^{C}$ & $\begin{array}{c}M_{\mathrm{n}}^{\mathrm{d}} \\
\text { (theor.) }\end{array}$ & $M_{\mathrm{n}}{ }^{\mathrm{e}}$ & $M_{\mathrm{n}}{ }^{\mathrm{f}}$ & $\mathrm{PDI}^{\mathrm{g}}$ & $\underset{\%}{\text { conv. }^{e}}$ \\
\hline 1 & 0.96 & - & - & 7 & 20 & 885 & 973 & 320 & 1.62 & 67 \\
\hline 2 & - & 1.79 & - & 4 & 36 & 549 & 494 & 350 & 1.21 & 48 \\
\hline 3 & - & - & 1.37 & 5 & 27 & 762 & 524 & 390 & 1.16 & 50 \\
\hline
\end{tabular}

aNo ROP was detected with pentaerythritol (4). bMonomer to initiator ratio. CInitiator to catalyst ratio. dCalculated according to Equation 1 and Equa-

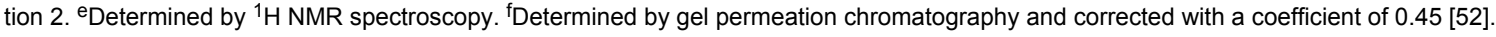
gPolydispersity index determined by gel permeation chromatography.

As shown in Table 1 and Table 2, full conversion is observed for all ROPs of $\varepsilon$-caprolactone initiated by the various alcohols while conversions in the range of $50-70 \%$ were obtained for the ROP of rac-lactide, which afforded oligomers. The incomplete conversion can be explained by the viscous nature of the reaction mixture, resulting in PLA formation and limiting the polymerization process. Besides, increasing the amount of alcohol and consequently the initiator/catalyst ratio causes a decrease of the molecular weight $\left(M_{\mathrm{n}}\right)$ and an increase of the polydispersity $\left(\mathrm{PDI}=M_{\mathrm{w}} / M_{\mathrm{n}}\right)$. This is closely linked to the degree of polymerization, designated as $D P_{\mathrm{n}}$ and defined according to Equation 1 $[53,54]$.

$$
\begin{aligned}
\overline{D P}_{\mathrm{n}, \text { theor }} & =\frac{n(\text { monomer })}{n(\text { precatalyst })+n(\text { alcohol })} \\
& =\frac{M_{\mathrm{n}}(\text { theor })}{M_{0}} ; \quad M_{0}=114.16 \mathrm{~g} \cdot \mathrm{mol}^{-1} \\
& M_{\mathrm{n}}(\text { theor })=\overline{D P}_{\mathrm{n}, \text { theor }} \cdot M_{0}
\end{aligned}
$$

For the ROP of $\varepsilon$-CL, Table 1 shows discrepancies between theoretical and experimental values of $M_{\mathrm{n}}$, despite a complete conversion. These deviations, which are significant in some 
cases, can be explained by a backbiting process and the involvement of redistribution reactions (inter- and intra-transesterification reactions) [55]. In all cases, the values of both experimental and calculated $M_{\mathrm{n}}$ are low, and the PDIs measured by GPC indicate a poor control of molecular weight distribution.

An alternate approach for the solvent-free ROP (method B, Scheme 1), based on the use of sodium cations as decarboxylation agent and circumventing vacuum conditions, was also tested [47]. Polymerization data are summarized in Table 3. A conversion of $67 \%$ for $\varepsilon$-caprolactone and $83 \%$ for rac-lactide could be achieved by heating to $75^{\circ} \mathrm{C}$ for $75 \mathrm{~min}$ in the presence of $\mathrm{NaBPh}_{4}$. Raising the heating time did not lead to a higher conversion.

Both polymerization pathways (A and B) lead to the desired polymers. Heating in vacuo is more efficient for the ROP of $\varepsilon$-caprolactone for which a conversion of $100 \%$ was always observed. However the highest conversion for $r a c$-lactide of $83 \%$ was achieved by using $\mathrm{NaBPh}_{4}$ as decarboxylating agent. Alcohols 1-4 initiate the ring-opening polymerization and form linear (benzyl alcohol, ethylene glycol) and star-branched (glycerol, pentaerythritol) polyesters. In comparison to their linear analogues, star-branched polymers feature lower crystallinity, lower melt viscosities and smaller hydrodynamic volume [5658]. The crystallinity (defined according to Equation 3 with $\Delta H_{\mathrm{c}}$ being the crystallization enthalpy, and $\Delta H^{\prime}$ the enthalpy of fusion of PCL, $\Delta H^{\prime}=161.1 \mathrm{~J} \cdot \mathrm{g}^{-1}$ ) affects directly the melting temperature $\left(T_{\mathrm{m}}\right)$. Thus, a decrease of molecular weight causes a decrease of the $T_{\mathrm{m}}$. Analysis of the crystallinity of the various polycaprolactones by differential scanning calorimetry is summarized in Table 4. DSC profiles are depicted in Supporting Information File 2 (Figure S1).

$$
\text { crystallinity }=\frac{\Delta H_{\mathrm{c}}}{\Delta H^{\prime}}
$$

Samples with molecular weight in the 1100-1500 Da range (Table 4), show similar $T_{\mathrm{m}}$ and $T_{\mathrm{c}}$, although the endings of the chains are different. However, values for the crystallinity decrease from 50\% (benzyl alcohol, 1) through 44\% (glycerol, 2) to $35 \%$ (pentaerythritol, 4).

From a mechanistic point of view, the formation of the target polymers can be postulated by the in situ decarboxylation of BMIM-2- $\mathrm{CO}_{2}$, which generates free $\mathrm{N}$-heterocyclic carbene species. In the absence of BMIM-2- $\mathrm{CO}_{2}$, the mixture of $\varepsilon$-caprolactone or $\mathrm{rac}$-lactide and initiator alcohols remained unchanged under otherwise identical conditions, even for an extended period of time, underlining the decisive role of the imidazolium-2-carboxylate species in the polymerization process. Moreover and under atmospheric pressure, we have observed from thermogravimetric measurements that BMIM-2$\mathrm{CO}_{2}$ is stable up to $90{ }^{\circ} \mathrm{C}$ and then undergoes a substantial weight-loss, corroborating a previous report published by Louie and co-workers [51]. Under the temperature conditions of ROP reactions, i.e., $75^{\circ} \mathrm{C}$, the decarboxylation is induced either in vacuo (method A) or by the addition of $\mathrm{NaBPh}_{4}$ (method B). On the basis of previous studies reported by Waymouth and Hedrick [34], we suggest that the in situ generated N-hetero-

\begin{tabular}{|c|c|c|c|c|c|c|c|c|c|}
\hline entry & cyclic ester & $\begin{array}{c}1 \\
\mathrm{mmol}\end{array}$ & $\begin{array}{c}2 \\
\mathrm{mmol}\end{array}$ & $\mathrm{M} / \mathrm{I}^{\mathrm{a}}$ & $\mathrm{I} / \mathrm{C}^{\mathrm{b}}$ & $\begin{array}{c}M_{\mathrm{n}}{ }^{\mathrm{C}} \\
\text { (theor) }\end{array}$ & $M_{\mathrm{n}}{ }^{\mathrm{d}}$ & conv. $^{\mathrm{d}}[\%]$ & $\mathrm{PDI}^{\mathrm{d}}$ \\
\hline 1 & $\varepsilon-C L$ & 0.96 & - & 9 & 19 & 1119 & 565 & 67 & 1.38 \\
\hline 2 & rac-LA & 0.96 & - & 7 & 19 & 1388 & 540 & 83 & 1.59 \\
\hline 3 & rac-LA & - & 1.79 & 3 & 36 & 767 & 813 & 90 & 1.33 \\
\hline
\end{tabular}

aMonomer to initiator ratio. bInitiator to catalyst ratio. ${ }^{\mathrm{c} C}$ Calculated according to Equation $1 .{ }^{\mathrm{d} D e t e r m i n e d}$ by ${ }^{1} \mathrm{H}$ NMR spectroscopy. ${ }^{\mathrm{d} P o l y d i s p e r s i t y ~}$ index determined by gel permeation chromatography.

Table 4: DSC data recorded for several polycaprolactones synthesized in this study.

\begin{tabular}{ccccccc} 
entry & alcohol & $\begin{array}{c}M_{\mathrm{n}} \\
\left(\mathrm{g} \cdot \mathrm{mol}^{-1}\right)^{\mathrm{b}}\end{array}$ & $T_{\mathrm{c}}\left({ }^{\circ} \mathrm{C}\right)$ & $\begin{array}{c}\Delta H_{\mathrm{C}} \\
\left(\mathrm{J} \cdot \mathrm{g}^{-1}\right)\end{array}$ & $T_{\mathrm{m}}\left({ }^{\circ} \mathrm{C}\right)$ & $\begin{array}{c}\Delta H_{\mathrm{m}} \\
\left(\mathrm{J} \cdot \mathrm{g}^{-1}\right)\end{array}$ \\
\hline 1b & 1 & 1130 & 20.36 & 80.01 & 46.71 & 88.56 \\
3b & 3 & 1460 & 22.17 & 71.40 & 47.27 & 71.06 \\
4b & 4 & 1163 & 24.39 & 56.72 & 47.08 & 56.71 \\
\hline
\end{tabular}

${ }^{a}$ Corresponds to the same entries of Table $1 .{ }^{b}$ Determined by ${ }^{1} \mathrm{H}$ NMR spectroscopy. ${ }^{\mathrm{C}}$ Percentage of $\mathrm{crystallinity} .{ }^{\mathrm{d}} H^{\prime}(\mathrm{PCL})=161.1 \mathrm{~J} \cdot \mathrm{g}^{-1}$. 
cyclic carbene acts as a nucleophilic species and leads to the opening of cyclic esters (initiation step, Scheme 2). The protonation of the formed zwitterionic acylimidazole intermediate by the alcohol initiator followed by the attack of the thereby obtained alkoxide regenerates the carbene species. The chain propagation is by the attack of the newly formed hydroxy- terminated monomer (I) on another zwitterionic intermediate (propagation step, Scheme 2). As a consequence, if the ratio of monomer to alcohol initiator is too low, the latter can compete with the formed hydroxy-terminated monomers/polymers to initiate the formation of a new polymer chain, and the propagation is stopped. In this case oligomers rather than polymers are

Initiation step<smiles>CCCCn1cc[n+](C)c1C(=O)O</smiles><smiles>C=C(C(=O)O[14CH3])C(=O)O[Na]</smiles>

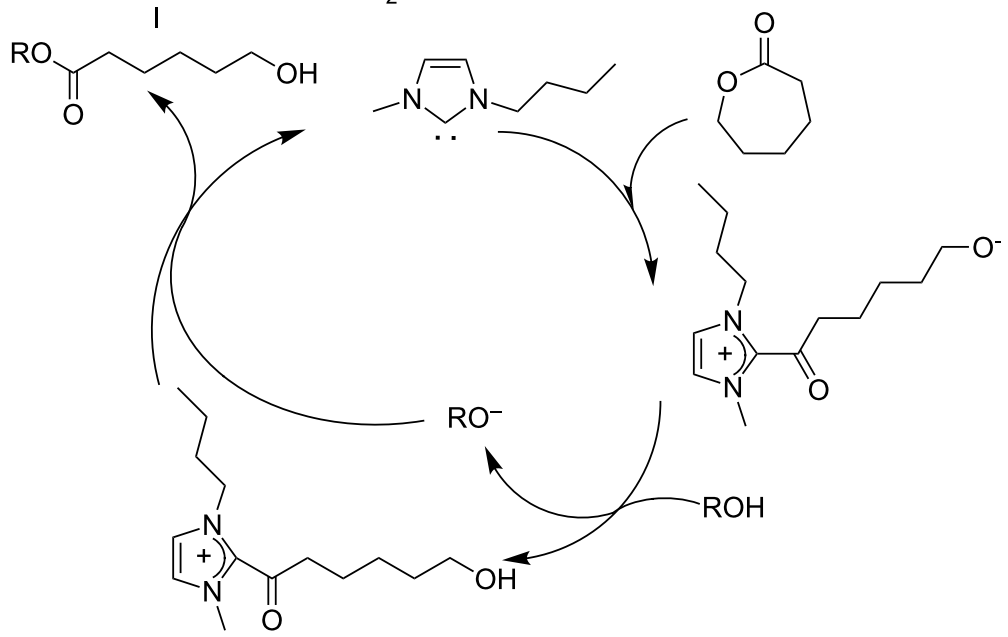

Propagation step

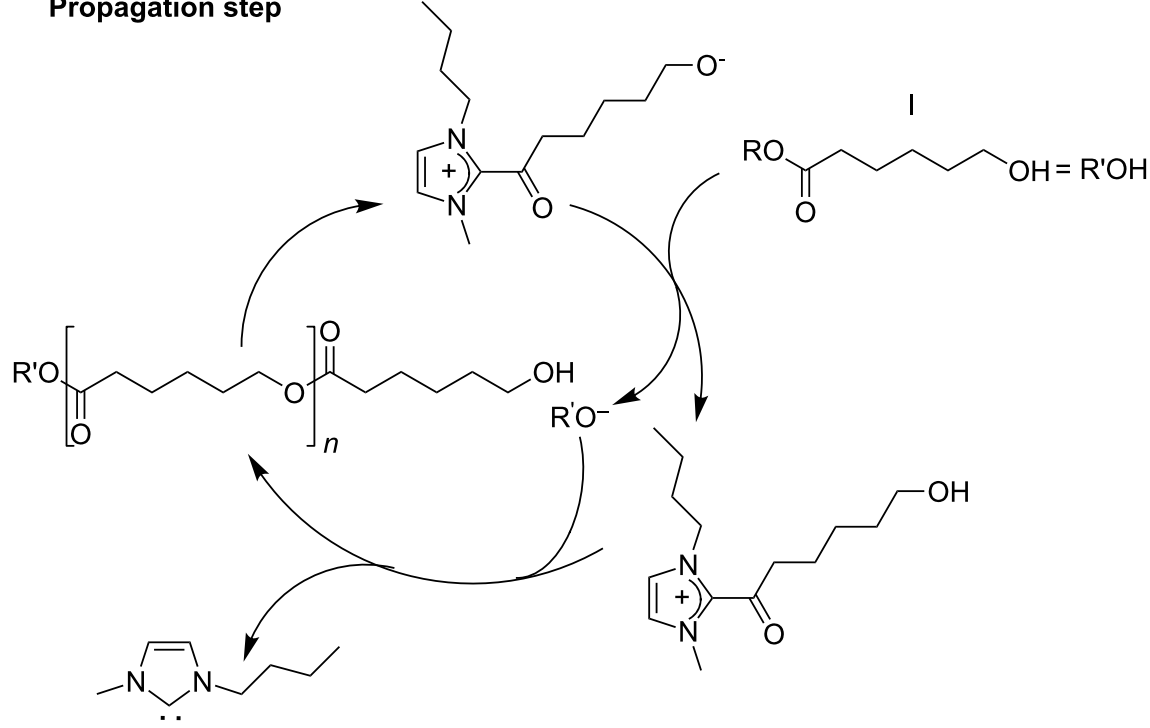


detected. Further experimental attempts to trap carbene species and the proposed intermediates are currently in progress in our laboratory.

Regarding method $\mathrm{B}$, which uses $\mathrm{NaBPh}_{4}$ as the decarboxylating agent, the reaction does not occur in vacuo. Thus, and on the basis of a previous study reported by Tommasi et al. [47], we suggest that the liberated carbon dioxide reacts with the alcohol initiator $\mathrm{ROH}$, leading to the formation of a $\mathrm{ROC}(\mathrm{O}) \mathrm{O}^{-}$ anion (monobenzylcarbonate if benzyl alcohol is used as initiator, Scheme 3). The expelled proton reacts with the carbene species and deactivates the catalyst. The decrease of the amount of the initiating alcohol and the bit by bit deactivation of BMIM-2- $\mathrm{CO}_{2}$ can explain the incomplete conversion observed by comparison with method A.<smiles>CCCCN1[C]N(C)[C]N1CCCC</smiles><smiles>C=C=C[I+]=Cc1ccccc1COCC</smiles><smiles>CCCCN1C=CN(C)[Y]1CC(C)C</smiles>

Scheme 3: In situ formation of monobenzylcarbonate and deactivation of $\mathrm{N}$-heterocyclic carbene.

Furthermore, this dependence between the amount of alcohol and the length of the chain confirms the proposed monomeractivated mechanism for the ring-opening polymerization of $\varepsilon$-caprolactone and rac-lactide (Scheme 2) $[20,27,28,33,49]$.

\section{Conclusion}

In this contribution, we have reported that BMIM-2- $\mathrm{CO}_{2}$ can be an active precatalyst for the solvent-free ring-opening polymerization of $\varepsilon$-caprolactone and rac-lactide. A conversion of $100 \%$ could be achieved for $\varepsilon$-CL by using different alcohols in vacuo, while the addition of $\mathrm{NaBPh}_{4}$ appears to be more efficient for rac-LA, reaching a conversion of $83 \%$. Thus, in view of these results, BMIM-2- $\mathrm{CO}_{2}$ can be considered as a potential versatile precatalyst. In addition, its facile preparation, in only one-step with a satisfactory yield (66\%) and from commercial $n$-butylimidazole and dimethyl carbonate, increases its attractiveness and its green character compared to the direct use of stable and active $\mathrm{N}$-heterocarbenes, which require several synthetic steps [59]. Therefore, we support the use of BMIM-2- $\mathrm{CO}_{2}$ as a welladapted alternative with respect to green polymerization approaches, (solvent-free conditions, no metal-based catalyst) as reported in this manuscript. However, the formation of higher molecular weight polymers with low polydispersities still remains to be improved. Further work in this direction is underway.

\section{Supporting Information}

\section{Supporting Information File 1}

Experimental details and characterization of the compounds synthesized.

[http://www.beilstein-journals.org/bjoc/content/ supplementary/1860-5397-9-73-S1.pdf]

\section{Supporting Information File 2}

Differential scanning calorimetry (DSC) profiles.

[http://www.beilstein-journals.org/bjoc/content/

supplementary/1860-5397-9-73-S2.pdf]

\section{Acknowledgements}

The authors gratefully acknowledge the Centre National de la Recherche Scientifique (CNRS, France) and the University of Burgundy (Dijon, France) for support of this work. The authors thank also Dr. Jean-Claude Chambron for the correction of the manuscript.

\section{References}

1. Albertsson, A.-C.; Varma, I. K. Biomacromolecules 2003, 4, 1466-1486. doi:10.1021/bm034247a

2. Sune Negre, J. M.; Manich Bou, A.; Tico Grau, J. R.; Bel Prieto, E. Cienc. Pharm. 1997, 7, 79-86.

3. Molpeceres, J.; Guzman, M.; Aberturas, M. R.; Chacon, M.; Berges, L. J. Pharm. Sci. 1996, 85, 206-213. doi:10.1021/js950164r

4. Ohya, Y. Bio Ind. 2007, 24, 16-27.

5. Viinikainen, A.-K.; Göransson, H.; Huovinen, K.; Kellomäki, M.; Törmälä, P.; Rokkanen, P. J. Mater. Sci.: Mater. Med. 2009, 20 , 1963-1969. doi:10.1007/s10856-009-3747-8

6. Jérôme, C.; Lecomte, P. Adv. Drug Delivery Rev. 2008, 60, 1056-1076. doi:10.1016/j.addr.2008.02.008

7. Hess, R.; Douglas, T.; Myers, K. A.; Rentsch, B.; Rentsch, C.; Worch, H.; Shrive, N. G.; Hart, D. A.; Scharnweber, D. J. Biomech. Eng. 2010, 132, 021001. doi:10.1115/1.4000194 
8. Oyana, A.; Uchida, M.; Choong, C.; Triffitt, J.; Jones, J.; Ito, A. Biomaterials 2005, 26, 2407-2413. doi:10.1016/j.biomaterials.2004.07.048

9. Chang, K.-Y.; Hung, L.-H.; Chu, I.-M.; Ko, C.-S.; Lee, Y.-D. J. Biomed. Mater. Res., Part A 2010, 92A, 712-723. doi:10.1002/jbm.a.32198

10. Hietala, E.-M.; Maasilta, P.; Juuti, H.; Nuutinen, J.-P.; Harjula, A. L. J.; Salminen, U.-S.; Lassila, R. Thromb. Haemostasis 2004, 92, 1394-1401. doi:10.1160/TH04-02-0124

11. Kricheldorf, H. R.; Berl, M.; Scharnagel, N. Macromolecules 1988, 21 , 286-293. doi:10.1021/ma00180a002

12. O'Keefe, B. J.; Hillmyer, M. A.; Tolman, W. B. J. Chem. Soc., Dalton Trans. 2001, 2215-2224. doi:10.1039/B104197P

13. Gibson, V. C.; Marshall, E. L. Compr. Coord. Chem. I/ 2004, 9, 1-74. doi:10.1016/B0-08-043748-6/09010-1

14. Dove, A. P.; Gibson, V. C.; Marshall, E. L.; White, A. J. P.; Williams, D. J. Chem. Commun. 2001, 283-284. doi:10.1039/b008770j

15. Chisholm, M. H.; Delbridge, E. E. New J. Chem. 2003, 27, 1167-1176. doi:10.1039/b300101f

16. Duda, A.; Penczek, S. Macromolecules 1995, 28, 5981-5992. doi:10.1021/ma00122a001

17. Biela, T.; Kowalski, A.; Libiszowski, J.; Duda, A.; Penczek, S. Macromol. Symp. 2006, 240, 47-55. doi:10.1002/masy.200650807

18. Palard, I.; Schappacher, M.; Soum, A.; Guillaume, S. M. Polym. Int 2006, 55, 1132-1137. doi:10.1002/pi.1984

19. Kiesewetter, M. K.; Shin, E. J.; Hedrick, J. L.; Waymouth, R. M. Macromolecules 2010, 43, 2093-2107. doi:10.1021/ma9025948

20. Kamber, N. E.; Jeong, W.; Waymouth, R. M.; Pratt, R. C.; Lohmeijer, B. G. G.; Hedrick, J. L. Chem. Rev. 2007, 107, 5813-5840. doi:10.1021/cr068415b

21. Jeong, W.; Hedrick, J. L.; Waymouth, R. M. J. Am. Chem. Soc. 2007, 129, 8414-8415. doi:10.1021/ja072037q

22. Matsumura, S. Adv. Polym. Sci. 2006, 194, 95-132. doi:10.1007/12_030

23. Gross, R. A.; Kumar, A.; Kalra, B. Chem. Rev. 2001, 101, 2097-2124. doi:10.1021/cr0002590

24. Liu, J.; Liu, L. Macromolecules 2004, 37, 2674-2676. doi:10.1021/ma0348066

25. Casas, J.; Persson, P. V.; Iversen, T.; Córdova, A. Adv. Synth. Catal. 2004, 346, 1087-1089. doi:10.1002/adsc.200404082

26. Dove, A. P.; Pratt, R. C.; Lohmeijer, B. G. G.; Waymouth, R. M.; Hedrick, J. L. J. Am. Chem. Soc. 2005, 127, 13798-13799. doi:10.1021/ja0543346

27. Connor, E. F.; Nyce, G. W.; Myers, M.; Möck, A.; Hedrick, J. L. J. Am. Chem. Soc. 2002, 124, 914-915. doi:10.1021/ja0173324

28. Kamber, N. E.; Jeong, W.; Gonzalez, S.; Hedrick, J. L.; Waymouth, R. M. Macromolecules 2009, 42, 1634-1639. doi:10.1021/ma802618h

29. Dove, A. P.; Pratt, R. C.; Lohmeijer, B. G. G.; Culkin, D. A.; Hagberg, E. C.; Nyce, G. W.; Waymouth, R. M.; Hedrick, J. L. Polymer 2006, 47, 4018-4025. doi:10.1016/j.polymer.2006.02.037

30. Raynaud, J.; Absalon, C.; Gnanou, Y.; Taton, D. J. Am. Chem. Soc. 2009, 131, 3201-3209. doi:10.1021/ja809246f

31. Dove, A. P.; Li, H.; Pratt, R. C.; Lohmeijer, B. G. G.; Culkin, D. A.; Waymouth, R. M.; Hedrick, J. L. Chem. Commun. 2006, 2881-2883. doi:10.1039/b601393g

32. Culkin, D. A.; Jeong, W.; Csihony, S.; Gomez, E. D.; Balsara, N. P.; Hedrick, J. L.; Waymouth, R. M. Angew. Chem., Int. Ed. 2007, 46, 2627-2630. doi:10.1002/anie.200604740
33. Csihony, S.; Culkin, D. A.; Sentman, A. C.; Dove, A. P.; Waymouth, R. M.; Hedrick, J. L. J. Am. Chem. Soc. 2005, 127, 9079-9084. doi:10.1021/ja050909n

34. Kamber, N. E.; Kiesewetter, M. K.; Hedrick, J. L.; Waymouth, R. M. Polym. Prepr. 2006, 47, 570-571.

35. Holbrey, J. D.; Reichert, W. M.; Tkatchenko, I.; Bouajila, E.; Walter, O.; Tommasi, I.; Rogers, R. D. Chem. Commun. 2003, 28-29. doi:10.1039/b211519k

36. Azouri, M.; Andrieu, J.; Picquet, M.; Cattey, H. Inorg. Chem. 2009, 48, 1236-1242. doi:10.1021/ic801870w

37. Azouri, M.; Andrieu, J.; Picquet, M.; Richard, P.; Hanquet, B.; Tkatchenko, I. Eur. J. Inorg. Chem. 2007, 4877-4883. doi:10.1002/ejic.200700590

38. Voutchkova, A. M.; Feliz, M.; Clot, E.; Eisenstein, O.; Crabtree, R. H. J. Am. Chem. Soc. 2007, 129, 12834-12846. doi:10.1021/ja0742885

39. Tudose, A.; Delaude, L.; André, B.; Demonceau, A. Tetrahedron Lett. 2006, 47, 8529-8533. doi:10.1016/j.tetlet.2006.09.139

40. Tudose, A.; Demonceau, A.; Delaude, L. J. Organomet. Chem. 2006, 691, 5356-5365. doi:10.1016/j.jorganchem.2006.07.035

41. Voutchkova, A. M.; Appelhans, L. N.; Chianese, A. R.; Crabtree, R. H. J. Am. Chem. Soc. 2005, 127, 17624-17625. doi:10.1021/ja056625k

42. Rijksen, C.; Rogers, R. D. J. Org. Chem. 2008, 73, 5582-5584. doi:10.1021/jo800578b

43. Bridges, N. J.; Hines, C. C.; Smiglak, M.; Rogers, R. D. Chem.-Eur. J. 2007, 13, 5207-5212. doi:10.1002/chem.200700055

44. Smiglak, M.; Holbrey, J. D.; Griffin, S. T.; Reichert, W. M.; Swatloski, R. P.; Katritzky, A. R.; Yang, H.; Zhang, D.; Kirichenko, K.; Rogers, R. D. Green Chem. 2007, 9, 90-98. doi:10.1039/b610421e

45. Picquet, M.; Poinsot, D.; Stutzmann, S.; Tkatchenko, I.; Tommasi, I.; Wasserscheid, P.; Zimmermann, J. Top. Catal. 2004, 29, 139-143. doi:10.1023/B:TOCA.0000029796.11969.ec

46. Tommasi, I.; Sorentino, F. Tetrahedron Lett. 2006, 47, 6453-6456. doi:10.1016/j.tetlet.2006.06.106

47. Tommasi, I.; Sorentino, F. Tetrahedron Lett. 2005, 46, 2141-2145. doi:10.1016/j.tetlet.2005.01.106

48. Zhou, H.; Zhang, W.-Z.; Liu, C.-H.; Qu, J.-P.; Lu, X.-B. J. Org. Chem. 2008, 73, 8039-8044. doi:10.1021/j0801457r

49. Naik, P. U.; Petitjean, L.; Refes, K.; Picquet, M.; Plasseraud, L. Adv. Synth. Catal. 2009, 351, 1753-1756. doi:10.1002/adsc. 200900280

50. Naik, P. U.; Refes, K.; Sadaka, F.; Brachais, C.-H.; Boni, G.; Couvercelle, J.-P.; Picquet, M.; Plasseraud, L. Polym. Chem. 2012, 3, 1475-1480. doi:10.1039/c2py20056b

51. Van Ausdall, B. R.; Glass, J. L.; Wiggins, K. M.; Aarif, A. M.; Louie, J. J. Org. Chem. 2009, 74, 7935-7942. doi:10.1021/jo901791k

52. Biela, T.; Duda, A.; Penczek, S. Macromol. Symp. 2002, 183, 1-10. doi:10.1002/1521-3900(200207)183:1<1::AID-MASY1>3.0.CO;2-Q

53. Cowie, J. M. G. Polymers: Chemistry and Physics of Modern Materials, 2nd ed.; Blackie Academic \& Professional: London, 1991.

54. Gilbert, R. G.; Hess, M.; Jenkins, A. D.; Jones, R. G.; Kratochvil, P.; Stepto, R. F. T. Pure Appl. Chem. 2009, 81, 351-353. doi:10.1351/PAC-REC-08-05-02

55. Labet, M.; Thielemans, W. Chem. Soc. Rev. 2009, 38, 3484-3504. doi:10.1039/b820162p

56. Sanda, F.; Sanada, H.; Shibasaki, Y.; Endo, T. Macromolecules 2002, 35, 680-683. doi:10.1021/ma011341f

57. Peppas, N. A.; Argade, A.; Bhargava, S. J. Appl. Polym. Sci. 2003, 87, 322-327. doi:10.1002/app.11444 
58. Lemmouchi, Y.; Perry, M. C.; Amass, A. J.; Chakraborty, K.; Schacht, E. J. Polym. Sci., Part A: Polym. Chem. 2007, 45, 3975-3985. doi:10.1002/pola.22151

59. Arduengo, A. J., III; Krafczyk, R.; Schmutzler, R.; Craig, H. A.; Goerlich, J. R.; Marshall, W. J.; Unverzagt, M. Tetrahedron 1999, 55 , 14523-14534. doi:10.1016/S0040-4020(99)00927-8

\section{License and Terms}

This is an Open Access article under the terms of the Creative Commons Attribution License

(http://creativecommons.org/licenses/by/2.0), which permits unrestricted use, distribution, and reproduction in any medium, provided the original work is properly cited.

The license is subject to the Beilstein Journal of Organic Chemistry terms and conditions:

(http://www.beilstein-journals.org/bjoc)

The definitive version of this article is the electronic one which can be found at: doi:10.3762/bjoc. 9.73 